Texts Prepared for Delivery at Paul Krugman's Honorary Doctorate by Three Lisbon Universities on 27 February, 2012

Jorge Braga de Macedo Paul Krugman

J. Silva Lopes

Working Paper n. 566

July 2012 


\title{
TEXTS PREPARED FOR DELIVERY AT PAUL KRUGMAN'S HONORARY DOCTORATE BY THREE LISBON UNIVERSITIES ON 27 FEBRUARY, 2012
}

\author{
Jorge Braga de Macedo \\ Nova SBE
}

\author{
Paul Krugman \\ Princeton University
}

\author{
J. Silva Lopes \\ ISEG, UTL
}

\begin{abstract}
Three texts were prepared for delivery at the first honorary doctorate awarded simultaneously by three Lisbon universities on 27 February, 2012: an introduction, a lecture and a comment. The event included the award of member of the Lisbon Academy of Science (ACL) by Manuel Jacinto Nunes, dean of the economics and finance section of ACL who proposed his name and Olivier Blanchard's on the $30^{\text {th }}$ anniversary of James Tobin receiving an honorary doctorate from Nova University.

On 24 February, Paul Krugman visited ACL and participated in a session of the project dubbed "Letter to the lusofonia Queen". Since this project is promoted by Nova SBE's Center for Globalization and Governance and has been featured in some of the graduate courses, a short note on the meeting is included in annex.

On 15 June, the three universities authorized an edition in Portuguese and donated the copyrights to a student award on "Krugman economics", in a way still to be determined by the editor. The lecture and the comment will be translated as soon as a suitable publisher is found. Since a lot of the teaching at Nova SBE is in English, it seemed appropriate to reproduce the original texts in the order in which they were presented. A lively question and answer period was also recorded by Nova TV and should be made available in the book, together with highlights of the media coverage.
\end{abstract}

Introduced as a "militant economist", he speaks about a crisis "his mind loves but does not let the heart forget the poor and the unemployed". The Nobel prize winner described as a"progressist pessimist of the world economy" concludes with a severe indictment of the profession. "In normal times, when things are going pretty well, the world can function reasonably well without professional economic advice. It's in times of crisis, when practical experience suddenly proves useless and events are beyond anyone's normal experience, that we need professors with their models to light the path forward. And when the moment came, we failed".

The comment, by the official responsible for Paul Krugman's mission to Portugal in 1976, contains an equally dire prediction: "I would very much like to see in the near future the weakening of the influence not only of freshwater economists but also of their conservative European followers. But I fear that this will not happen until we find ourselves in a more calamitous situation than at present". Fortunately Silva Lopes closes in the hope "that the ideas of Paul Krugman will soon have more influence in policy makers than at present seems to be the case". 


\section{ECONOMISTA MILITANTE}

Jorge Braga de Macedo

Não tenho como agradecer a confiança que os três magníficos me expressaram na reitoria da técnica há três semanas. Em seu nome apresento o economista militante, pessimista progressista, investigador eficiente que gosta de literatura e ciência ficção, herdeiro tanto de Paul Samuelson como de George Orwell e Isaac Azimov, comandante que não puxa pelos galões, grande teórico de baixa estatura, barbudo que nunca é barbant nem barboso, cozinheiro gourmet que se veste como um alfarrabista, jornalista encorajado a ir para o Tesouro na canção de rock $n^{\circ} 77$ ("we need you on the frontline, not just writing for The New York Times")!

Mais. Na última entrevista antes de chegar a Portugal é apresentado assim: "ele está no seu elemento porque adora uma boa crise. A economia global dá-lhe uma grande tela para desenhar uma imagem depressiva, mas ele também agita para acção que a seu ver nos pode tirar da bagunça em que estamos metidos". Imperturbável, esclarece no seu blogue "Consciência de um Liberal" que foi entrevistado pela revista Playboy mas nem por isso usa "um agrafe no umbigo".

São tantos os contrastes e as matizes deste americano intensamente privado que - qual José Régio apaixonado - não consigo "dizer sem falsidade coisa que ditas já não são verdade”. Fingindo a mesma licença poética, declaro já múltiplas pertenças: formei-me na clássica mas, logo após regressar da revolução angolana, entrei na nova pela mão de Alfredo de Sousa, ele próprio recém-saído da técnica. Conheci o laureado no Grémio Literário quando entrevistei "os cinco do MIT" para a revista Nação e Defesa. Não me fardei para a refeição mas adverti na introdução $\left(n^{\circ} 2\right.$, p. 176): “dificilmente se pode criticar o notável trabalho desenvolvido, referindo - como alguns têm feito - que se trata de 'estudantes"'. Identifiquei-os por ordem alfabética Andy Abel, Miguel Beleza, Jeff Frankel e Ray Hill. 
Apresento aqui o quinto em três secções, porventura alusivas às partes interessadas ISEG, Nova SBE e esta casa.

\section{Supressão incestuosa da desvalorização cambial}

Terminava apresentando "Paul Krugman, formado em Economia na Universidade de Yale, que publicou um artigo sobre efeitos deflacionistas da desvalorização cambial no Journal of International Economics e teve importantes intervenções" na Conferência sobre a Economia Portuguesa, realizada na Fundação Gulbenkian em Outubro de 1976.

$\mathrm{Na}$ altura em que o ex - Centro de Sociologia Militar começou a editar Nação e Defesa ainda se ouviam ecos da conferência proferida por Serge Kolm, na qual o radical propôs "uma desvalorização para salvar a revolução" e os capitães de Abril retorquiram ao Professor "no nosso país não se desvaloriza!".

Trinta anos depois, a convite de Silva Lopes, que idealizara as missões económicas do MIT, Krugman voltou à Gulbenkian com outros velhos combatentes. Num anfiteatro quase deserto enunciou a tese da "supressão incestuosa", segundo a qual o "pensamento de grupo" impõe tal conformidade que ninguém se atreve a contestá-lo para não ser excluído desse mesmo grupo.

Ouvir os militares que derrubaram o Estado Novo a amplificar o apego à moeda estável (mesmo que não convertível) do seu criador estica certamente o conceito de grupo. Porém, os trabalhos de outro Nobel em Economia de Princeton, Daniel Kahneman (Thinking, fast and slow, 2011) confirmam experimentalmente a tese da supressão incestuosa: somos rápidos e superficiais ou lentos e esforçados. O ditado "depressa e bem há pouco quem" revela o optimismo do nosso povo. Para os Nobel de Princeton, não há quem!

A regra WYSIATI (o que se vê é tudo o que há, "Não queriam mais informação para não estragar a história", p.88) ajuda a perceber o "esticão do euro" na economia portuguesa. 
Cunhei o termo em 1998 para sugerir como o bom aluno da integração europeia foi vítima da sua má constituição fiscal. Num trabalho que escrevemos em Yale em 1978 sobre as consequências económicas do 25 abril, apontamos para o papel dos salários no ajustamento conseguido pela desvalorização real do escudo. O artigo, injustamente esquecido, abria com citações comparando os ensinamentos das crises financeira com os de experiências laboratoriais, lembrando que tanto se pode diminuir o défice de pagamentos pela via dolorosa do corte no salário nominal como pela anestesia da desvalorização. Sabemos que o ajustamento foi interrompido por choques internos e externos obrigando a novo acordo com o FMI, ele próprio interrompido pelo fascínio da assinatura do tratado de Roma. Esse o padrão que levou ao esticão.

Certo é que o papel da taxa de câmbio real no ajustamento externo tem dividido os economistas desde o debate há quase cem anos entre Maynard Keynes e Bertil Ohlin e era um tema aceso de conversa entre Carlos Diaz, Pentti Kouri e Paul Krugman nas elegantes vivendas da Hillhouse Avenue que acolhiam o Departamento de Economia. Na Fundação Cowles, James Tobin mantinha-se alheio porque -como tantas vezes me disse: M é moeda não consigo pensar em $\mathrm{M}$ denotar importações, por isso fecho a economia ao comércio internacional - como Keynes tinha feito na Teoria Geral!

Os efeitos da desvalorização cambial no produto e no emprego são determinantes no debate pois que, para Keynes, não basta baixar o nível da despesa para eliminar o défice comercial, há que depreciar a moeda nacional em termos reais, ou seja sem que a inflação doméstica anule a desvalorização cambial. Numa conferência organizada pelo Banco de Portugal em Seteais nos finais de 1991, o laureado enunciou as suas famosas "lições de Massachusetts para a União Económica e Monetária”. Na linha do veterano de Princeton, Peter Kenen, Krugman considerou a solidariedade orçamental mais relevante para definir uma zona monetária óptima do que a mobilidade do trabalho ou do capital. Por isso na Zona Euro o desequilíbrio externo continua a ser relevante e até se torna mais perigoso na ausência do sinal de alarme do mercado cambial, que anuncia a desvalorização e realiza a expectativa dela. 
Tal como Diaz, Kouri, Tobin ou Kenen, Krugman não podia estar mais longe do discurso de posse pronunciado em 23 de Fevereiro de 2000 no Salão Nobre do Ministério das Finanças: "Ninguém analisa a dimensão macro da balança externa do Mississipi ou de qualquer outra região de uma grande união monetária (...) A ressaca após um forte endividamento pode ter consequências recessivas, mas não é um problema macroeconómico de balança de pagamentos".

Certamente, com um défice de 5\% em 2011, a nossa balança corrente melhorou de quatro em vez de dois pontos de PIB relativamente a 2010, com exportações a dois dígitos muito mais dinâmicas do que nos ajustamentos com desvalorização cambial. Mas não me falem no Mississipi a não ser para evocar o sonho de Martin Luther King!

\section{História contra Expectativas ou Oceano contra Lagos}

Além do seu premonitório livro de 1990, A idade das expectativas diminuídas (que iria desembocar no famoso Vendilhões da prosperidade) e da série "The Dismal Scientist" (coligida em The accidental theorist), tenho-me inspirado no artigo do Quarterly Journal of Economics "História contra Expectativas" e partilhado essa inspiração nas aulas. Vejamos aqui, na magna: se as pessoas se adaptam lentamente e descontam fortemente o futuro, se as economias externas são diminutas, a história torna-se decisiva e expectativas positivas não conseguem romper um equilíbrio de estagnação. Os custos de transacção que restringem as forças de concorrência específicas à tecnologia sugerem assim múltiplos equilíbrios na economia nacional ou mundial. Dependendo das condições iniciais, da dinâmica e das condições terminais, um processo de ajustamento pode levar a um «alto» ou «baixo» desenvolvimento, determinado pela história - do passado ou, com vénia para o padre António Vieira, do futuro.

Além das instituições, do conhecimento e da tecnologia, o grau de paciência colectiva torna-se um parâmetro crucial do cálculo da relevância de eventos futuros. A paciência aplica-se tanto aos comportamentos de poupança individual ou colectiva como às instituições de cooperação inter-temporais, de que é um bom exemplo o acordo que hoje liga mais de $80 \%$ dos nosso deputados. 
Pelo meu lado, assinei o tratado de Maastricht acreditando que a supervisão multilateral realizada pela Comissão Europeia ou pelo Fundo Monetário Internacional promoveria a emulação das melhores práticas - o tal equilíbrio institucional «alto» - em vez do contágio das piores práticas - o equilíbrio institucional «baixo». Não perdi a esperança na primeira solução mas a experiência mostrou que crises las hay - nacionais, regionais e mundiais!

Mesmo quem argumenta que existe uma instabilidade inata na moderação, financeira, política e até intelectual, como Krugman, reconhece que a minimizou. Assim chegamos ao tema do dia: economia na crise.

Bob Hall, lendário professor do MIT que migrou para a costa oeste, descreveu num trabalho inédito de 1976 a diferença entre economistas de água salgada que entendem que o governo pode gerir a crise causada pelos espíritos animais dos investidores ao passo que os de água doce atribuem a crise ao próprio governo!

Nas aulas de introdução à economia usamos o manual de Krugman e sua mulher Robin Wells, que tem nome, ao contrário de Mary Marshall, autora fantasma dos Príncipios que tornaram clássico o seu marido Alfred e que aqui saúdo.

Água doce austríaca de Friedrich Hayek contra água salgada de Keynes, esse um tema favorito de exame, até pela memória do dueto musical entre ambos na vizinhança do Fed, clip com muito som e mais liquidez:

We've been goin' back $\mathrm{n}$ forth for a century

[Keynes] I want to steer markets,

[Hayek] I want them set free

There's a boom and bust cycle and good reason to fear it

[Hayek] Blame low interest rates.

[Keynes] No it's the animal spirits 


\section{Processo}

Por fim, um apontamento sobre o processo que nos trouxe a esta magnífica aula. Há quase três anos, a secção de economia e finanças da Academia das Ciências de Lisboa começou a ter reuniões regulares convocadas pelo decano Jacinto Nunes. Espicaçada pela crise financeira e pela visita da rainha Isabel à LSE, pretendeu substituir a vaga deixada aberta pela morte de Tobin. Recolhida uma vintena de candidaturas dos sócios, Krugman foi o mais votado mas a secção propôs também Olivier Blanchard e ambos foram ratificados em 2010 no plenário de efectivos da classe.

Sem demora os novos sócios aceitaram a eleição e começámos a preparar uma conferência em colaboração com uma jornalista anónima (e exclusiva!). Na verdade, os efeitos da crise financeira global na percepção pública dos economistas haviam sido objecto de uma carta à rainha enviada pela Academia Britânica. Introduzindo as ciências naturais e os países do Sul (nomeadamente CPLP) concebemos uma "raínha lusófona" à qual queremos enviar uma carta. O Banco de Portugal, o Instituto de Investigação Científica Tropical e outras instituições foram postas ao corrente do projecto, que devia marcar o 30 aniversário da eleição de Tobin em Abril de 2011 (plano A).

A deterioração do ambiente português e europeu aconselhou a adoptar o plano B, debates regulares aproveitando as viagens de uns e de outros e módulos nos cursos de mestrado da Nova SBE. Assim economistas como Renato Flores, da Fundação Getúlio Vargas, físicos como os confrades Vilela Mendes da técnica e Jean Pierre Contzen, da Academia Real da Bélgica, biólogos como o confrade Rui Malhó da clássica, aqui presente, professores de gestão como Joe Santos, do MIT Sloan foram trocando impressões, tendo Krugman participado no debate de sexta feira passada na presença de Jacinto Nunes e Silva Lopes, os dois outros ex-ministros das finanças aqui presentes, de Paulo Pitta e Cunha, mestre e amigo que infelizmente não pode estar aqui hoje, e de António Pinto Barbosa, um dos incontornáveis gémeos económicos da nova, meus colegas, meus amigos, meus irmãos. 
Dos três economistas da Academia a quem coube dirigir o Ministério das Finanças, aquele que não passou pelo Banco de Portugal pode agradecer o acolhimento institucional desde que o doutorando Krugman aterrou no gabinete da Avenida da República. Faço-o na pessoa do governador aqui presente, Carlos Costa.

Em todo este processo contei ainda com o apoio fraterno de José Luís Cardoso, formado na técnica onde ensinou longos anos até migrar para a clássica. Ele fará a primeira pergunta após o comentário.

Ouçamos o economista militante falar da economia na crise - que sua razão adora sem deixar o coração esquecer os pobres e desempregados. Pessimista progressista da economia mundial! 


\section{ECONOMICS IN THE CRISIS}

Paul Krugman

To say the obvious: we're now in the fourth year of a truly nightmarish economic crisis. I like to think that I was more prepared than most for the possibility that such a thing might happen; developments in Asia in the late 1990s badly shook my faith in the widely accepted proposition that events like those of the 1930s could never happen again. But even pessimists like me, even those who realized that the age of bank runs and liquidity traps was not yet over, failed to realize how bad a crisis was waiting to happen - and how grossly inadequate the policy response would be when it did happen.

And the inadequacy of policy is something that should bother economists greatly indeed, it should make them ashamed of their profession, which is certainly how I feel. For times of crisis are when economists are most needed. If they cannot get their advice accepted in the clinch - or, worse yet, if they have no useful advice to offer - the whole enterprise of economic scholarship has failed in its most essential duty.

And that is, of course, what has just happened.

In what follows I will talk first about the general role of economics in times of crisis. Then I'll turn to the specifics of the role economics should have been playing these past few years, and the reasons why it has for the most part not played this role. At the end I'll talk about what might make things better the next time around.

\section{Crises and useful economics}

Let me start with a paradox: times of economic disturbance and disorder, of crisis and chaos, are times when economic analysis is especially likely to be wrong. Yet such times are also when economics is most useful. 
Why the paradox? Well, first of all, consider what economics can contribute in calm times.

The answer, I'd submit, is surprisingly little. OK, economists can explain why the system works the way it does, and offer useful advice about reforms that would make it better; there's always use for good microeconomics.

But if you're trying to make predictions, economists won't have much to contribute. Take the case of exchange rates, one of my original home areas of research. In ordinary times, it's very, very hard for structural models to beat a random walk - that is, models based on an attempt to track the forces moving the exchange rate, such as changes in prices and changes in monetary policy, are barely if at all better than the simple guess that tomorrow's exchange rate will be the same as today's. And it's even harder to beat an experienced trader, who has been through many fluctuations and has developed both useful rules of thumb about price patterns and a strong intuitive sense of what comes next.

Economic modelers may be better placed to engage in policy analysis. But even here, experienced practical hands may have the better advice to offer; they know from experience what will soothe the markets, what will rile them, and as long as events remain within the range of their experience, this informal understanding may trump the inevitably simplified and stylized analysis of those who know the world through equations and diagrams.

But now let there be a severe disruption that pushes the economy into terrain experienced practical men have never seen - say, an environment in which credit markets collapse, or short-term interest rates on assets considered safe are pushed all the way to zero. Because there are large and normally unforeseen disruptions, the sheer unpredictability of events will mean many bad economic forecasts, so if you ask how nearly right economists are in their ability to predict events, they will seem to be doing very badly compared with calmer times. But the question you should ask is how economists are doing compared 
with those who use other ways to understand the world, and in particular how they are doing compared with sober, serious, experienced men in suits. And it is precisely in disturbed times that economists can and sometimes do offer dramatically better predictions and policy judgments than what we normally consider wise men.

Take, for example, the relationship between deficits and interest rates. It's not an example chosen at random, of course; I believe that it gets to the heart both of the nature of the crisis we're in and the terrible failure of economists - plus, not incidentally, it happens to be something I personally got right. More about that shortly. But for now, let's just focus on what we should have known.

Most practical men, confronted with the prospect of unprecedented deficits in the United States, the UK, and elsewhere, extrapolated from their usual experience, in which increased borrowing drives up interest rates. And so there were widespread predictions of sharp rate rises. Most famously, perhaps, Morgan Stanley predicted in late 2009 that interest rates on 10-year US bonds, then around 3.5 percent, would shoot up to 5.5 percent in 2010; in early 2011 Pimco's legendary head, Bill Gross - who had correctly predicted low rates in 2010,predicted a rate spike by the summer. And in each case these views were very widely held.

But economists who knew basic macroeconomic theory - specifically, the IS-LM model, which was John Hicks's interpretation of John Maynard Keynes, and at least used to be in the toolkit of every practicing macroeconomist - had a very different take. By late 2008 the United States and other advanced nations were up against the zero lower bound; that is, central banks had cut rates as far as they could, yet their economies remained deeply depressed. And under those conditions it was straightforward to see that deficit spending would not, in fact, raise rates, as long as the spending wasn't enough to bring the economy back near full employment. It wasn't that economists had a lot of experience with such situations (although Japan had been in a similar position since the mid-1990s). It was, rather, that economists had special tools, in the form of models, that allowed them 
to make useful analyses and predictions even in conditions very far from normal experience.

And those who knew IS-LM and used it - those who understood what a liquidity trap means - got it right, while those with lots of real-world experience were wrong. Morgan Stanley eventually apologized to its investors, as rates not only stayed low but dropped; so, later, did Gross. As I speak, deficits remain near historic highs - and interest rates remain near historic lows.

Crises, then, are times when economics and economists can and should really prove their worth. And I'd like to say that some of my friends and colleagues did; maybe some of them will say that I did OK, too. But one can't say that of the profession as a whole. On the contrary, all too many of us had rejected the very kinds of analysis that were to prove so useful. And more than that, all too many actively opposed the policy measures the crisis called for.

Actually, let me talk a bit more about the failures of the economics profession in this crisis.

\section{What should economists have known?}

The most common accusation against economists in this crisis is that they failed because they didn't see it coming. Even the Queen of England has demanded that economists explain their failure to predict the crisis. But I would actually defend my colleagues against assertions that this predictive lapse was, in and of itself, all that much of a failure.

To take the most absurd case, nobody could realistically have demanded that the economics profession predict that Lehman Brothers would go down on September 15, 2008 , and take much of the world economy with it. In fact, it's not reasonable to criticize economists for failing to get the year of the crisis right, or any of the specifics of how it 
played out, all of which probably depended on detailed contingencies and just plain accident.

What you can criticize economists for - and indeed, what I sometimes berate myself for is failing even to see that something like this crisis was a fairly likely event. In retrospect, it shouldn't have been hard to notice the rise of shadow banking, banking that is carried out by non-depository institutions such as investment banks financing themselves through repo. And it shouldn't have been hard to realize that an institution using overnight borrowing to invest in longer-term and somewhat illiquid assets was inherently vulnerable to something functionally equivalent to a classic bank run - and, furthermore, that the institutions doing this were neither backed by deposit insurance nor effectively regulated. Economists, of all people, should have been on guard for the fallacy of misplaced concreteness, should have realized that not everything that functions like a bank and creates bank-type systemic risks looks like a traditional bank, a big marble building with rows of tellers.

And I plead guilty to falling into that fallacy. I was vaguely aware of the existence of a growing sector of financial institutions that didn't look like conventional banks, and weren't regulated like conventional banks, but engaged in bank-like activities. Yet I gave no thought to the systemic risks.

Even more broadly, economists should have been aware of the dangers of leverage. This was hardly a new concern. Back in 1933 - yes, 1933 -- Irving Fisher published his classic paper on debt deflation, that is, on the way high levels of debt create the possibility of a self-reinforcing downward spiral. And the paper remains astonishingly relevant; aside from a few archaisms of style it could have been written from today's headlines. So remembering Fisher all by itself should have been enough to rouse at least a few worries as household debt rose dramatically relative to income, not just in America, but in a number of European nations too. 
Again, I plead guilty to negligence. I had especially little excuse for being oblivious to these dangers given that I had actually laid great stress on balance-sheet factors in causing financial crises in emerging market. True, those crises had a lot to do with currency mismatch - basically, private debt in other countries' currencies, so that a speculative attack on a currency could quickly translate into a crippling collapse of domestic demand. But I and others should have seen that this was only one possible channel for balance-sheet crises, that plunges in housing prices or for that matter income could have the same effect.

So economists fell down on the job by not seeing what were in retrospect clear warning signs that the kind of crisis that struck in 2008 was both possible and becoming increasingly likely.

Yet I would submit that these predictive failures were venial sins compared with the much more important failure to speak with anything like a unified voice on how to respond to the crisis when it came.

\section{Depression economics and how it was lost}

Suppose that something like the crisis of 2008 had struck, say, 40 years ago. At that point, I believe, there would have been widespread agreement on the part of economists about what to do. Everyone in the profession knew IS-LM analysis; everyone understood the case for expansionary monetary policy to fight recessions when it was available, and at least understood the argument that there are times when conventional monetary policy is not available and fiscal policy may be the best tool at hand.

By the time the crisis actually did strike, however, all too many of my colleagues had either rejected or forgotten the analysis they needed. And as a result there was a cacophony of voices when we needed a chorus, intellectual fog at the very moment when we desperately needed clarity of vision. 
How did that happen? There was, of course, a deep divide within macroeconomics about the right kind of model, and I believe that one side of that divide got it very wrong (and I am, of course, right in that view!). But that is the sort of thing that happens in any field, and the principle that I personally am always right isn't a good basis for intellectual inquiry. What was wrong, instead, were three consequences of that intellectual divide that reflect very badly on the profession. First, one side of the divide became intellectually insular in a way that proved disastrous in the crisis. Second, much of the profession reacted to the dispute by running away from the whole issue of slumps and what to do about them, again crippling the response to crisis. Finally, even the "right" side of the divide - that is, my side - let itself be bullied into a style of analysis that was inherently biased against any kind of readiness for crisis.

\section{Macroeconomics: What went wrong?}

I assume that most of those hearing or reading this speech at all closely are aware of the great divide that emerged in macroeconomics in the 1970s. For those who aren't familiar with the story: in the 1930s Keynesian economics emerged as a response to depression, and by the 1950s it had come to dominate the field. There was, however, an undercurrent of dissatisfaction with that style of modeling, not so much because it fell short empirically as because it seemed intellectually incomplete. In "normal" economics we assume that prices rise or fall to match supply with demand. In Keynesian macroeconomics, however, one simply assumes that wages and perhaps prices too don't fall in the face of high unemployment, or at least fall only slowly.

Why make this assumption? Well, because it's what we see in reality - as confirmed once again by the experience of peripheral European countries, Portugal included, where wage declines have so far been modest even in the face of very high unemployment. But that's an unsatisfying answer, and it was only natural that economists would try to find some deeper explanation. 
The trouble is that finding that deeper explanation is hard. Keynes offered some plausible speculations that were as much sociological and psychological as purely economic which is not to say that there's anything wrong with invoking such factors. Modern "New Keynesians" have come up with stories in terms of the cost of changing prices, the desire of many firms to attract quality workers by paying a premium, and more. But one has to admit that it's all pretty ad hoc; it's more a matter of offering excuses, or if you prefer, possible rationales, for an empirical observation that we probably wouldn't have predicted if we didn't know it was there.

This, understandably, wasn't satisfying to many economists. So there developed an alternative school of thought, which basically argued that the apparent "stickiness" of wages and prices in the face of unemployment was an optical illusion. Initially the story ran in terms of imperfect information; later it became a story about "real" shocks, in which unemployment was actually voluntary; that the real business cycle approach.

And so we got the division of macroeconomics. On one side there was "saltwater" economics - people, who in America tended to be in coastal universities, who continued to view Keynes as broadly right, even though they couldn't offer a rigorous justification for some of their assumptions. On the other side was "freshwater" - people who tended to be in inland US universities, and who went for logically complete models even if they seemed very much at odds with lived experience.

Obviously I don't believe any of the freshwater stories, and indeed find them wildly implausible. But economists will have different ideas, and it's OK if some of them are ones I or others dislike.

What's not OK is what actually happened, which is that freshwater economics became a kind of cult, ignoring and ridiculing any ideas that didn't fit its paradigm. This started very early; by 1980 Robert Lucas, one of the founders of the school, wrote approvingly of how people would giggle and whisper when facing a Keynesian. What's remarkable about that is that this was all based on the presumption that freshwater logic would 
provide a plausible, workable alternative to Keynes - a presumption that was not borne out by anything that had happened in the 1970s. And in fact it never happened: over time, freshwater economics kept failing the test of empirical validity, and responded by downgrading the importance of evidence.

This was, by the way, not a symmetric story: saltwater economists continued to read Lucas and his successors. So only one side of the divide shut itself off from opposing views.

And this inward turning had what can now be seen as a fateful consequence: freshwater macro, basically something like half or more the macroeconomics field, stopped teaching not only new Keynesian research but the past as well. And what that meant was that when crisis struck, we had half a generation of economists who not only had no model that could make sense of the crisis, but who blithely reproduced classic errors of the past. Keynes spent a good part of his magnum opus, The General Theory of Employment, Interest, and Money, refuting Say's Law - the proposition that income must be spent, so that shortfalls of demand are impossible, and government spending in particular cannot add to demand. Yet in 2008 and 2009 we had well-known professors from Chicago and elsewhere opposing stimulus because ... income must be spent, so government spending cannot increase demand. Intellectually, much of the profession had unknowingly regressed 75 years.

Worse yet, the consequences were not limited to the acolytes of freshwater economics. Quite a few economists responded to the bitter warfare between schools of thought by running away from business cycle issues in general. I know whereof I speak: when Robin Wells and I began writing our principles of economics textbook, the general view was that you should focus on long-run growth, and relegate things like recessions and recoveries to a brief section at the end. Why? Because focusing on the long run was safer, less likely to get the committees that choose textbooks riled up. 
The problem, of course, is exactly the one Keynes himself diagnosed in his most famous quote:

"But this long run is a misleading guide to current affairs. In the long run we are all dead. Economists set themselves too easy, too useless a task if in tempestuous seasons they can only tell us that when the storm is long past the ocean is flat again."

Finally, all was not well even in saltwater economics.

Even though saltwater economists had too much reality sense to accept the notion that unemployment is an illusion and recessions are voluntary, indeed optimal, they were not immune to the push for more rigor and more math. You might say that they suffered from rigor envy. And so New Keynesian models tried to have as few deviations from perfect markets as possible, and tried to embed their analysis in a framework where everyone knew what was going on and behaved optimally except for a few ad hoc constraints. The result was DSGE - dynamic stochastic general equilibrium - models, which looked a lot like real business cycle models, except for the assumed wage/price stickiness.

So what's wrong with that? Well, DSGE models have three aspects that make them unsuited to times like these. First, they're unwieldy; you can't easily sketch out your argument on a piece of paper, and you can't easily translate it into ordinary language to explain it to a politician. Second, they normally assume that the data we see come from a regular process of random shocks, with strong incentives for the modeler to assume that the shocks are more or less normal, not involving large, low probability events - which leaves you unready for the Big One when it happens. Finally, the desire to make the things tractable tends to favor linearity, or at least models that can be done in terms of linear approximations; again, that's not a modeling style that leaves you ready to deal with sudden financial crisis, which may involve multiple equilibria and at the very least involves regime change in which the effects of a given policy or shock may suddenly become quite different. 
What we really needed, I'd submit, was a large number of economists ready and willing to go for good first approximations - quick and dirty but intellectually sophisticated approaches that would let them respond to a radically changed economic environment. Good old-fashioned IS-LM fits the bill, and as I see it the economists who did best in this crisis began with IS-LM, then backed it up later with simplified versions of New Keynesian analysis. But knowledge of IS-LM has become surprisingly rare, and comfort with it - appreciation of its virtues as well as its vices, and understanding of just how sophisticated it really is in some ways - has become even rarer.

And this has had terrible consequences.

\section{From analysis (or lack thereof) to policy}

In the years after 1980, and even more so, the years after 2000, the foundations for crisis were laid. The banking system became, de facto, largely unregulated and unsecured. Leverage rose, both fueling and fueled by housing bubbles (and, in Europe, the false confidence fostered by the creation of the euro). The conditions for disaster became ever better; and the disaster came.

Now what? The answer should have been simple, and backed by an overwhelming consensus. The immediate problem was a huge shortfall of demand, as the private sector moved from large financial deficit to large financial surplus. To avoid terrible effects on output and employment - effects that would only magnify the problems of excess leverage - we needed not just a rescue of the financial system but also strong government action to support demand while the wreckage was cleared.

What kind of action? There was and is a case for large-scale unconventional monetary policy, which in a zero-bound economy has to work largely through inflation expectations. But the more proximate tool, with the greatest known effectiveness, was fiscal policy, especially increased government purchases of goods and services. 
Anyone who knew the IS-LM model understood that. But too much of the economic profession had lost the hard-won understanding of earlier generations. So instead of a common call for action, we got acrimonious argument, with quite a few economists essentially acting as spoilers, undermining the credibility of those trying to get governments to do the right thing. And as I said, to a remarkable extent the "learned" arguments against government action were actually repeating fallacies like Say's Law and the Treasury View that had been thoroughly refuted in the 1930s.

Should we be surprised, then, that economic policy makers, after responding fairly effectively to the banking crisis, proceeded to lose the thread?

What happened, in fact, was that to a large extent policy makers ended up going for economic doctrines that made them feel comfortable, that corresponded to the prejudices of men not versed in economics.

Thus, it's normal to think of the economy as a whole as being like a family, which must tighten its belt in hard times; it's also completely wrong. But lacking any clear message from the economists about how and why this is wrong, it became the common standard of discussion in America, where both Republicans and, alas, President Obama became very fond of the statement that the government should tighten its belt because families were tightening theirs.

It's also normal to think of economics as a morality play, a tale of sin and redemption, in which countries must suffer for their past excesses. Again, this normal reaction is wrong, or at least mostly wrong -mass unemployment does nothing to help pay off debt. But absent clear guidance from the people who are supposed to explain that economics is not, in fact, a morality play, moralizing became the core of economic policy thinking in Germany, and hence played a huge role in European policy more generally.

Finally, government officials who hang out with businessmen - and almost all of them do - naturally tend to be attracted to views that put business confidence at the heart of the economic problem. Sure enough, belief that one should slash spending even in a 
depressed economy, and that this would actually promote growth because it would have positive effects on confidence, spread like wildfire in 2010. There were some economic studies used to justify the doctrine of expansionary austerity - studies that quickly collapsed under scrutiny. But really, the studies became popular because they suited the prejudices of politicians, prejudices that would have been totally familiar to Herbert Hoover or Heinrich Brüning.

And so our response to the crisis has been utterly inadequate.

\section{The failure of economics}

The best you can say about economic policy in this slump is that we have for the most part avoided a full repeat of the Great Depression. I say "for the most part" because we actually are seeing a Depression-level slump in Greece, and very bad slumps elsewhere in the European periphery. Still, the overall downturn hasn't been a full 1930s replay. But all of that, I think, can be attributed to the financial rescue of 2008-2009 and automatic stabilizers. Deliberate policy to offset the crash in private spending has been largely absent.

And I blame economists, who were incoherent in our hour of need. Far from contributing useful guidance, many members of my profession threw up dust, fostered confusion, and actually degraded the quality of the discussion. And this mattered. The political scientist Henry Farrell has carefully studied policy responses in the crisis, and has found that the near-consensus of economists that the banks must be rescued, and the semi-consensus in favor of stimulus in the initial months (mainly because the freshwater economists were caught by surprise, and took time to mobilize) was crucial in driving initial policy. The profession's descent into uninformed quarreling undid all that, and left us where we are today.

And this is a terrible thing for those who want to think of economics as useful. This kind of situation is what we're here for. In normal times, when things are going pretty well, 
the world can function reasonably well without professional economic advice. It's in times of crisis, when practical experience suddenly proves useless and events are beyond anyone's normal experience, that we need professors with their models to light the path forward. And when the moment came, we failed. 


\title{
COMMENTS ON PAUL KRUGMAN'S PRESENTATION
}

\author{
Jose Silva Lopes
}

It is a great honor for me to comment on the presentation that Paul Krugman has just delivered to us. But this is also an intimidating challenge. How can I, with all my limitations, comment the ideas of one of the most brilliant and influential economists of the world today?

This is not the first time that I find myself in such a difficult situation. I faced similar problems when I met Paul Krugman for the first time, in 1976. At that time he was only 23 years old and he was still a PhD student in MIT. But I soon concluded that, in spite of the differences in our ages, in our institutional positions and in our familiarity with Portuguese economic problems, he was far better than me in analyzing those problems and in making proposals for their solution.

The presentation that he has delivered to us today is an excellent example of the relevance and quality of his work in dealing with the most important real world issues, instead of being directed, like that of many others, to theories, based on unrealistic assumptions and faulty models.

I believe that economic theories are closely influenced by the ideological preferences of those that originate them or agree with them. In my view, the starting assumptions of the theories of those that Paul Krugman classifies as freshwater economists are chosen not for their realism and relevance but with two other objectives. The first is to show, under the veil of scientific reasoning, that most of the State interventions in the economy are ineffectual or produce negative economic results, and that consequently market mechanisms must be free of government interferences. The second objective is to build models based on assumptions that make it possible to use of sophisticated mathematical method that bring academic prestige, even if they do not contribute at all to useful interpretations of real world economic phenomena and actual economic behavior. 
The freshwater economists can of course accuse the saltwater ones, in the opposite camp of the economic debate, of similar ideological bias. But I am of the opinion that there is a big difference between the two: the later ones are more committed to realism, while the former persist in their fanciful hypotheses, even after the facts of the real world, and in particular the crises of 2008-2009, show clearly how wrong they have been.

My worries about the present state of economic theories come more from their impact on economic policy makers than from their intrinsical validity. In the beginning of the present economic crisis in industrialized countries, Governments and Central Banks reacted by adopting expansionary monetary and fiscal policies. During an initial period, many of us believed that Keynesianism had returned. But that period turned out to be very short.

By 2010, most governments, and to a smaller extent some Central Banks, were back to conservative policies of demand restrictions, dominated much more by the objective of avoiding inflation than by that of stimulating the recovery.

I refrain from commenting the debates in the United States, about which Paul Krugman has written so much. But I cannot hide my alarm about what is being done in the Europe. We are all aware that macro-economic policies in Euro area countries are to a large extent dictated by Germany. The leading German economists and policy makers are strongly influenced by the freshwater thinking in the USA. But to that influence they add their own reasons for adopting policies of demand restriction.

The first of these reasons is their obsession with inflation, which is even stronger than that of the conservatives in the United States. Because of that obsession, they tend to oppose any fiscal and monetary policies that might involve risks, however slight, of pushing inflation above very low levels. The second reason is the moralist belief that fiscal sins have to be punished by fiscal expiation, i.e. by austerity, whatever its economic and social consequences may be.

I am of the opinion that countries like Portugal, Greece and Ireland can not escape severe restrictive fiscal policies, given the excessive weight of their foreign and public debts and their unsustainable external disequilibria. 
But, within the constraints of the European Monetary Union, the adjustments in those countries would be less painful if two conditions were met.

The first relates to the amount of external assistance provided by countries with large current account surpluses. If Portugal received more assistance, although with appropriate conditionality, the contraction of its economy would be less deep, because there would be more time to wait for the results of the improved competitiveness that structural measures are expected to produce. Those who propose harsh fiscal austerity argue that it will bring back the trust of private economic agents, and will therefore encourage them to invest more and consume more. However, the experience of the last two years has proved abundantly that this argument is a fallacy. The rating agencies downgrade the debt of countries with large fiscal and external disequilibria. But when these disequilibria begin to be corrected by austerity policies which depress growth, they downgrade it again, this time because the expected improvement of confidence does not materialize and economic growth turns out to be unsatisfactory.

The second - and more important - of the conditions that I mentioned above, is that the solution of the difficulties in indebted countries should require more expansionary domestic demand policies in those which have external surpluses.

The international payments system should recover the arguments of Keynes, in the Bretton Woods negotiations, in favor of symmetric adjustments not only in countries with deficits but also in those which have surpluses. Unfortunately such a change does not appear to be likely in the near future, despite the existing dangerous problem of big payments disequilibria on a world scale.

Germany should reduce its large current account surplus- which in recent years has fluctuated between 5 and 6 percent of GDP - by stimulating its domestic demand and thus increasing the exports of other Euro area countries.

But what we are seeing is that, in spite of brilliant performance of its exports, the rate of increase German domestic demand is projected to fall from an estimated 2,5\% in 2011 to around $1,5 \%$ in 2012.

The fiscal policy is a major contributor to this containment of domestic demand. According to recent forecasts of the European Commission, the cyclically adjusted public deficit in Germany is projected to fall from 1.3\% of GDP in 2011, to $0.7 \%$ in 2012 and to 
$0.4 \%$ in 1913 . And Germany has not only introduced in its constitution the principle of practically forbidding fiscal deficits in the future, but also has led other Euro area countries to accept the a similar rule, imposed by the Intergovernmental Treaty, which was signed two weeks ago.

The policies advocated by distinguished German economists and by the German Authorities might result in the elimination of deficits, both external and fiscal, in the more indebted countries of the Euro area, but at the cost of economic and social disasters. The surplus in Germany would end up by being also cut, since its exports would be negatively affected. But the new equilibrium would be reached at income levels which would be significantly lower across Europe than those which would achievable with more expansionary macro-economic policies.

I would very much like to see in the near future the weakening of the influence not only of freshwater economists but also of their conservative European followers. But I fear that this will not happen until we find ourselves in a more calamitous situation than at present.

My only hope that the ideas of Paul Krugman will soon have more influence in policy makers than at present seems to be the case. 
Annex "The lusofonia Queen"

Academia de Ciências de Lisboa $24^{\text {th }}$ February 2012

On $24^{\text {th }}$ February 2012 the economics and finance section of ACL met to debate a paper delivered by Rui Malhó, entitled "A Cell Biologist naive approach: notes on my contribution to "A letter to the lusofonia Queen"". The meeting was attended by Professors Jacinto Nunes, Paulo Pitta e Cunha, Jorge Braga de Macedo, who chaired the meeting, José Silva Lopes, António Pinto Barbosa, Rui Vilela Mendes, Rui Malhó, Paul Krugman, Helena Garrido. Doctors Ana Melo and Luís Goulão, biologists from the Tropical Research Institute wrote this note..

The "together alone" paradox depicted in the question of Queen Elizabeth to the LSE on November 2008, was tackled from a biological approach to trigger amultidisciplinary debate on the global financial crisis.

RM: Biological systems rely on intricate interactions between their players, both at the internal level and their relations with the exterior. Whatever decision is taken, it implies enormous risks that may lead to error, which in the vast majority of cases, are dissipated by the system's properties. Conversely, in human societies, the huge pressure that politicians do not error, leadsto a lot of subsequent errors.

Why did people not see the crisis arriving?

The regulators were too close to the problem to see it. There was cognitive bias and people chose to disregard the high probability that things could go wrong. In addition, the perception of what one thinks is good for him, may not be the really best for him.

Parallels between biological and society systems are hampered by moral constraints. Solidarity and altruism, which are absent from biological systems, are highly valued in societies, while parasitism and commensalism, driving forces for nature evolution, are morally indefensible.

Biological systems do not include bad consciousness, making networking their natural rule. Moving away from equilibrium disturbs the system, forcing it to adjust to a new condition.

Societies have less networking than nature. A possible regulation mechanism is to force information networking. However if regulation is too strong it will limit evolution and with sharing of information, assets will be lost.

Dealing with the crises, biological and society systems present similarities in their behavior. In both cases, alternative available resources will be thrived to satisfy the needs, even if they require more input. In the Portuguese case, an obvious alternative could be to emphasize connections with CPLP.

RVM introduced the coupling question, suggesting that problem is not the crisis itself, but the coupling between finances and interest rates, emphasizing the importance of the timing of intervention from the regulators.

PK mentioned evolutionary economics. 
Organisms' evolution occurs locally and takes place over time, maximizing reproductive success, often taking advantages from crises in detriment of equilibria.

If economics is done with the right spirit, some biological models cannot be applied.

Some aspects in economics can be modeled by physics.

The Queen's question is a wrong question. Financial crises are not new, they happen all the time and are recognizable. This time is different, but it is never different. At the surface it looks different, but on the basis there is always the same pattern.

In spite this time, more documentation is available from the past, people have a short memory regarding crises. In the immediate times people will save, but then they will forget and so will the regulators.People's perception of bank functions hasbeen misjudged. Lots of banks and products were unsupervised and unguaranteed.

PC questioned parallels between the biological world and the "human world", pointed Greece as a natural catastrophe and raised the question of whether there would be a biological model to solve the crisis. Information networking was suggested as an advance in society.

SL: Behavioral economics is a growing field from which we have more to learn than from biology. Sociology and history can give more support to understand and apply to crises. Different organisms; different behaviors. The way to solve a crisis in Germany can hardly be successfully applied to Portugal, due to personality differences.

APB asked PK if he would agree that there was some original misdiagnosis about the most relevant fragilities that of the Euro Zone. If so, might have this possibly contributed to a somewhat inadequate design of a proper monetary framework? (written question below)

LG valued the contribution of psychology, psychiatry and neurology to understand the crisis, framingbiology of thinking-organisms. Fear prevented us from seeing the crisis and difficulties in facing errors lead to more errors.Different geo-political references induce different information perceptions.Likewise, distinctaveragelife expectancy thrive different decisions and will to take risks.

AM: There are two levels of regulation in a cell - locally and globally. There is also an enormous redundancy of regulation mechanisms to overcome cell malfunctioning. Moreover, the efficiency of biological regulation relies on huge networking between every pathway of the system. Only this ensures life as a tightly regulated and thus successful process.

RM: We have to find accurately our place in the system. There is a difference between individual and collective behavior.Time scale is critical when applying biological models to behavioral ones.Man has social sciences,nature does not.

HG questioned how to relate biological models to finance markets. Nowadays economy is not the same as a couple of years ago. Can we apply the same models? 
BM: We have two minds - a shallow and a slow and lazy. Since the $2^{\text {nd }}$ is lazy we tend to use too much of the $1^{\text {st }}$,what limits rationality. It's easier to see the balances on others than in ourselves.

PK: This crisis was an asymmetric shock story.Europe is pretty close to a closed system.

"No economic theory can perform the feats its users have come to expect of it. (...) Too much of what happens in an economy depends on what people expect to happen."Through multiple perspectives, sights, networking and capacity of transmission between groups, a new attitude to face and overcome crises arises. The diversity of CPLP perspectives could contribute to put multidisciplinarywork in the agenda and to trigger public debate by academies and research universities. "Portuguese-speaking economists might transcend the silo curse in a world that is both highly connected and tribal" (Gillian Tett, FT).

\section{Question to Professor Krugman, raised by Prof. Antonio Pinto Barbosa:}

By the time of the creation of the Eurozone (EZ), the most important risk feared was a socalled asymmetric shock,

illustrated by a fall in demand in some specific member of the union. Conventional thinking emphasized the importance of labor mobility to the subsequent adjustment and, given the low labor mobility in the EZ, the asymmetric shock could set off a protracted recession in that country.

Now, after more than a decade since the launching of the euro, the big threat seems to come from another direction: not so much from an asymmetric demand shock but, instead, 1) from a sort of Minsky moment upon accumulated debts of some member states like Portugal and 2) from the impossibility of the afflicted sovereign state to step into the domestic bond market to cap interest rates, via its Central Bank intervention, when investors are massively pulling out of it. This seems to be, in some sense, the opposite of what the conventional analysis predicted: the big threat came not from insufficient demand caused by some asymmetric shock, but from persistent excess demand above production, an excess translated into a significant accumulation of external debt.

Question: Would you agree that there was some original misdiagnosis about the most relevant fragilities that of the EZ ? If so, might have this possibly contributed to a somewhat inadequate design of a proper monetary framework? 